\title{
50+ Likely Voters in North Carolina
}

Key Findings:

- Voters 65+ are the new swing: The race is a tie with voters 18+, in part because of huge drops in support for President Trump among the 65+ voter. In 2016, they gave Trump a 23-point margin, but now favor Vice President Biden by 7-points.

- The virus goes political: Just $52 \%$ of Trump voters $50+$ always wear masks in public places, compared to $92 \%$ of Biden voters. But more than 1 in 3 Biden voters know someone personally who has died from coronavirus, compared to 1 in 10 Trump voters.

- The vote shift is driven by voters' bleak view of Trump's handling of coronavirus. But voters $50+$ also trust Biden more to bring people together and strengthen Social Security and Medicare.

- Much divides these voters, but they are united by a desire to protect Social Security and strengthen Medicare.

\section{North Carolinar The 50+ Voter and the Presidential Election}

Now, if the election for President were held today...for whom would you vote?
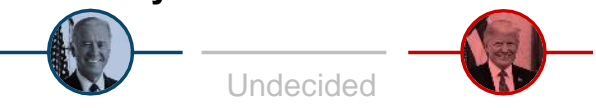

All $50+$

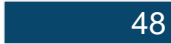

48

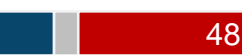

50-64

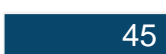

$65+$

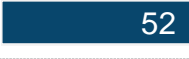

Democrats

Independents

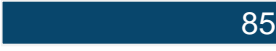

85

47

Republicans

Women

5

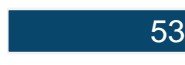

53

42

Men

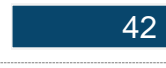

White

34

Black

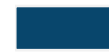

\section{8}

1

45

10

Who do you trust more to...

Help heal the divisions in the country caused by racism and racial tensions

Work effectively with both parties

Strengthen Social Security and protect Medicare

Look out for middle- and working-class people

Protect Americans over 50, especially in nursing homes, from coronavirus

Make health care more affordable

Rebuild the economy

Favorable or unfavorable view of...
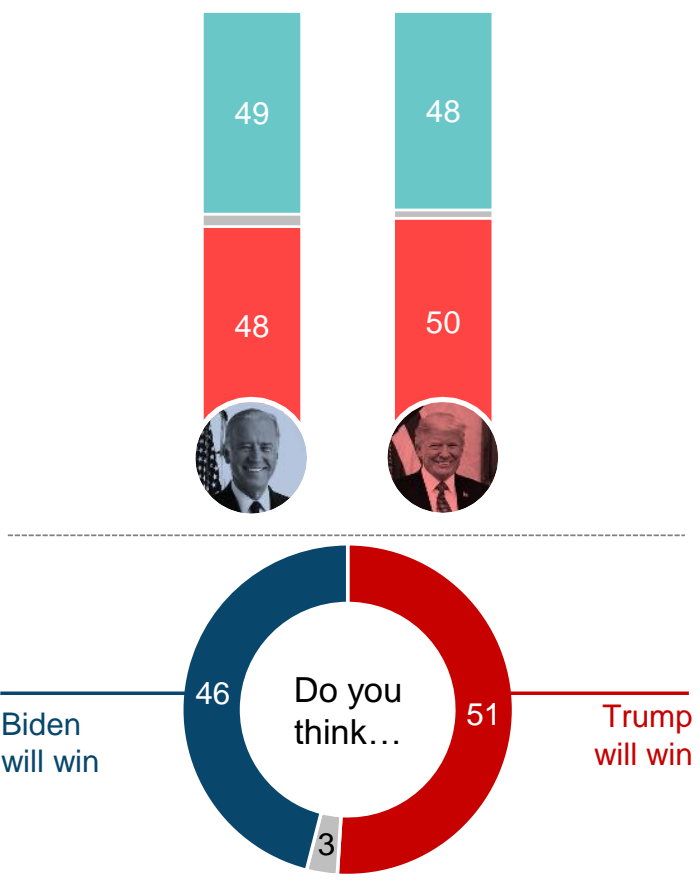

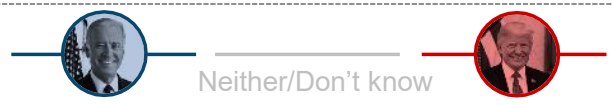

\begin{tabular}{|c|c|c|}
\hline 50 & 14 & 36 \\
\hline 49 & 15 & 36 \\
\hline 49 & 6 & 45 \\
\hline & 6 & \\
\hline
\end{tabular}

\begin{tabular}{|c|c|c|}
\hline 48 & 10 & 42 \\
\hline 47 & 10 & 43 \\
\hline 44 & 5 & 50 \\
\hline
\end{tabular}




\section{$78 \%$ of Biden voters $50+$ are \\ to vote for Biden \\ $81 \%$ \\ of Trump voters $50+$ are \\ $89 \% \begin{aligned} & \text { of Biden voters } 50+\text { are } \\ & \text { worried about Trump } \\ & \text { winning the election }\end{aligned}$ \\ $76 \% \begin{aligned} & \text { of Trump voters } 50+\text { are } \\ & \text { worried about Biden } \\ & \text { winning the election }\end{aligned}$}

How confident are you that votes made by mail will be counted accurately?

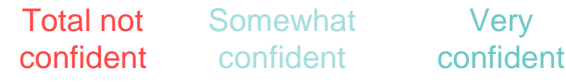

Biden Voters 50+

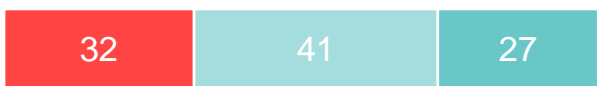

Trump Voters $50+$

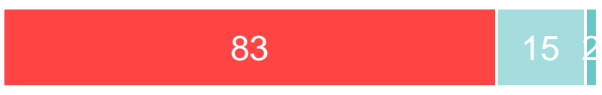

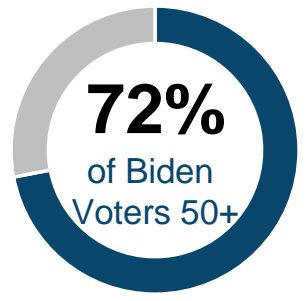

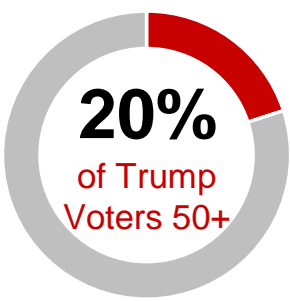

are confident that voting by mail will be safe
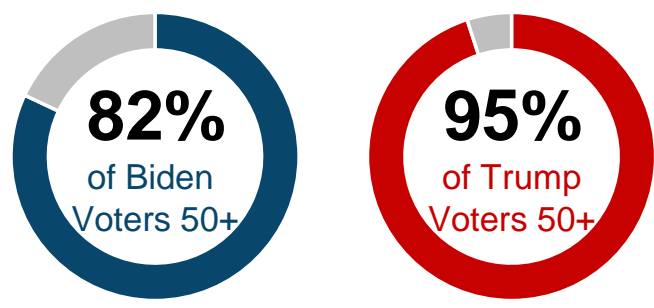

are confident that voting in person will be safe
In this November's general election, do you intend to vote by...
All $50+$

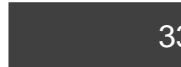

33 45 16
Biden Voters $50+$ 15 51 27
Casting your ballot in person during early voting

Voting by absentee ballot by mail
Trump Voters $50+$
52

41

How worried are you about not being able to vote because of the coronavirus?

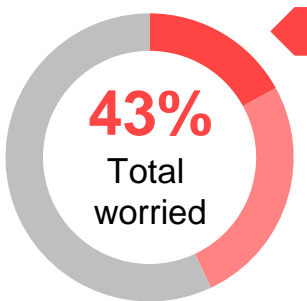

Biden Voters $50+$

\section{$17 \%$ Very worried}

\section{$6 \%$ Very worried}

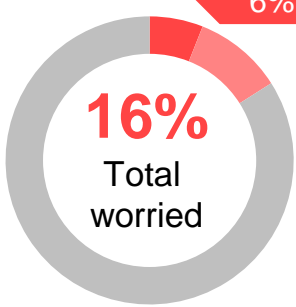

Trump Voters 50+ 
If the election for Senate were held today, who would you vote for?

\begin{tabular}{|c|c|c|c|}
\hline \multirow[b]{3}{*}{ All 50+ Voters } & & \multirow[b]{2}{*}{ Undecided/Other } & \\
\hline & Cal Cunningham & & Thom Tillis \\
\hline & 44 & 15 & 41 \\
\hline Democrats & \multicolumn{2}{|c|}{77} & 14 \\
\hline Independents & 45 & 14 & 41 \\
\hline Republicans & 17 & 80 & \\
\hline Men & 39 & 12 & 48 \\
\hline Women & 47 & 17 & 36 \\
\hline $50-64$ & 40 & 19 & 41 \\
\hline $65+$ & 48 & 11 & 41 \\
\hline
\end{tabular}

\section{Senate Favorability among 50+ Voters}

Please indicate if you have a favorable or unfavorable view of...

Cal Cunningham 
$\%$ worried about getting coronavirus

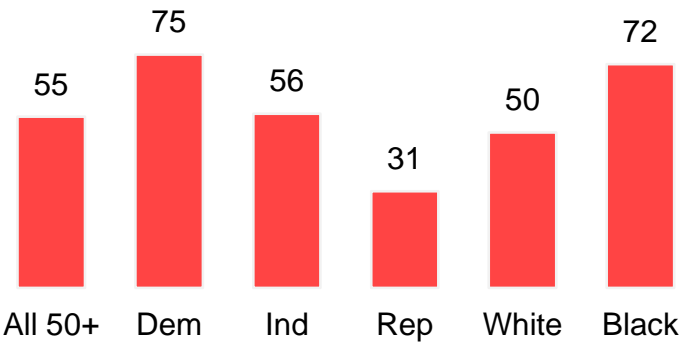

\% who knew someone personally who passed away from coronavirus

\begin{tabular}{lr} 
All $\mathbf{5 0 +}$ & $\mathbf{2 3}$ \\
\hline Democrats & 34 \\
\hline Independents & 22 \\
\hline Republicans & 9 \\
\hline White & 15 \\
\hline Black & 41
\end{tabular}

\section{Do you support or oppose how Trump is managing the coronavirus pandemic?}

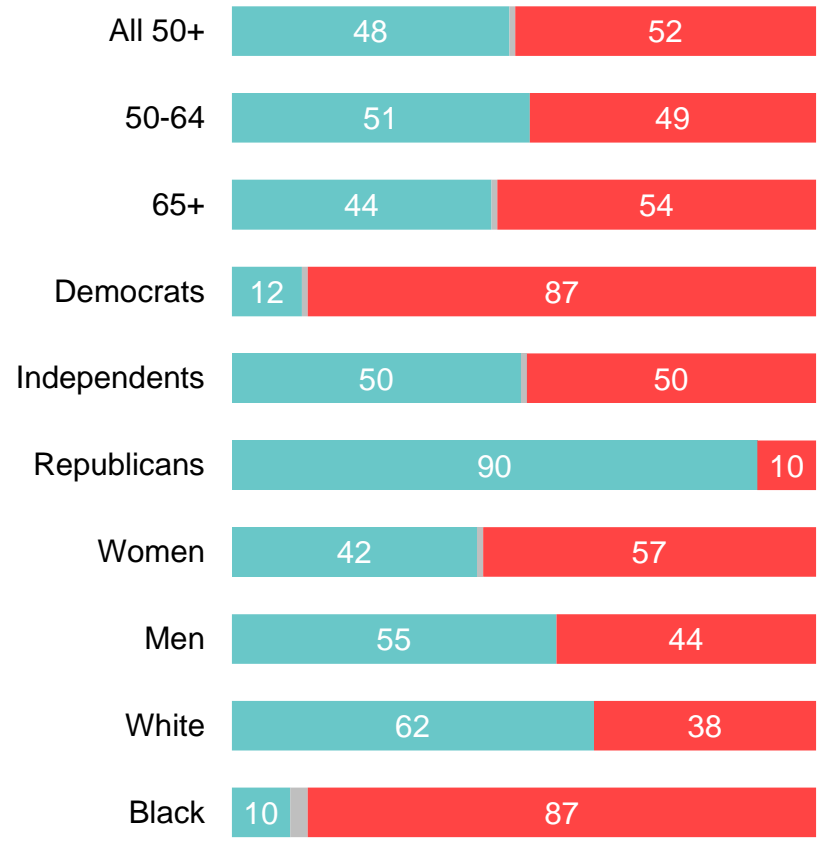

\section{Which worries you}

more, getting infected

with COVID-19 or

getting a vaccine for

COVID-19?

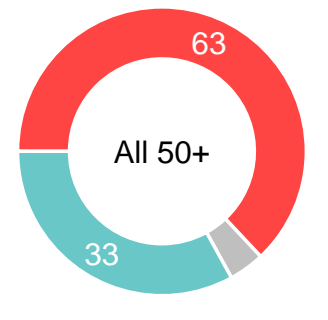

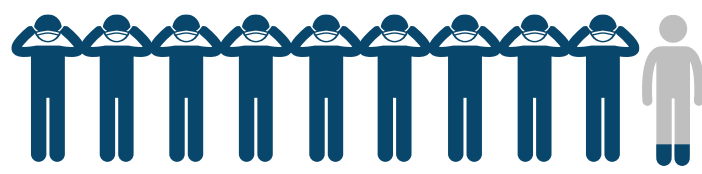

$92 \%$ of Biden voters $50+$ always wear a mask when they go out to public places

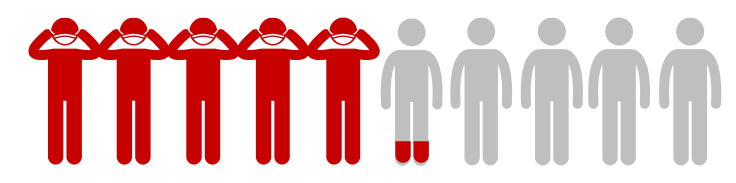

$52 \%$ of Trump voters $50+$ always wear a mask when they go out to public places
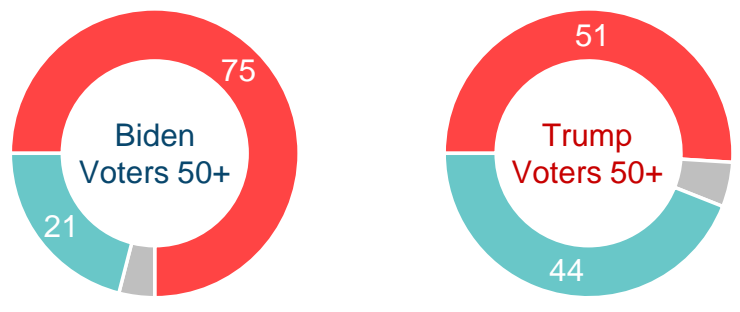

$\%$ confident in the safety and efficacy of COVID-19 vaccine if it came out...

- Next couple of months $\quad$ Early next year

All $50+$

41 63

Democrats

28 63

Independents

46 65

Republicans 52 61 
$\%$ worried about not being able to afford health care they or their family need

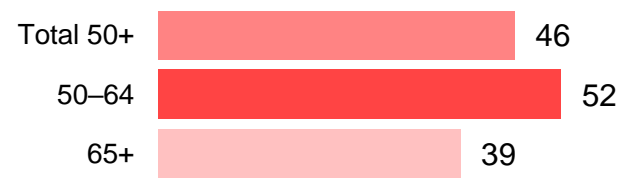

$\%$ worried about cuts to Social Security to pay for all the new spending and the budget crisis

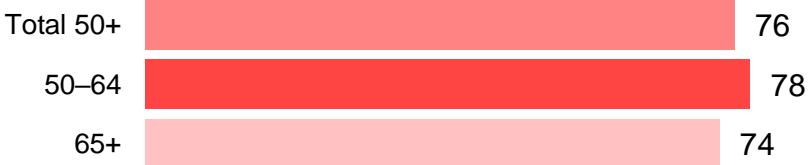

$\%$ worried about not being able to afford to retire

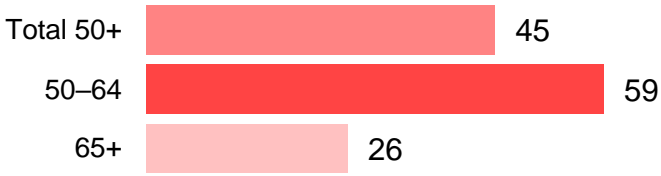

$\%$ who have gotten a health care bill they couldn't afford or skipped or rationed medication because they couldn't afford it

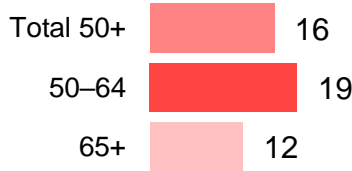

$\%$ who have been laid off or furloughed

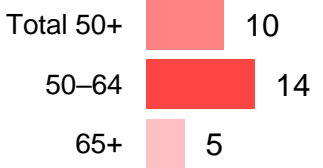

If a candidate wanted to do this, would that make you more or less likely to vote for the candidate?

Support protecting Social Security from cuts to workers' earned benefits/workers' benefits

Strengthening Medicare to make sure America's seniors get the healthcare they need

Allow Medicare to negotiate with drug companies for lower prices

Increase protections on nursing home residents during the coronavirus pandemic

Make quality, affordable long-term care options, from home care to nursing homes, available

Fight age discrimination in the workforce on behalf of people over 50

Provide family caregivers with a tax credit to help offset the money they spend caring for parents, spouses, or other loved ones

Support family caregivers with paid time off to care for parents, spouses, or other loved ones
70

68

64 


\section{Methodology}

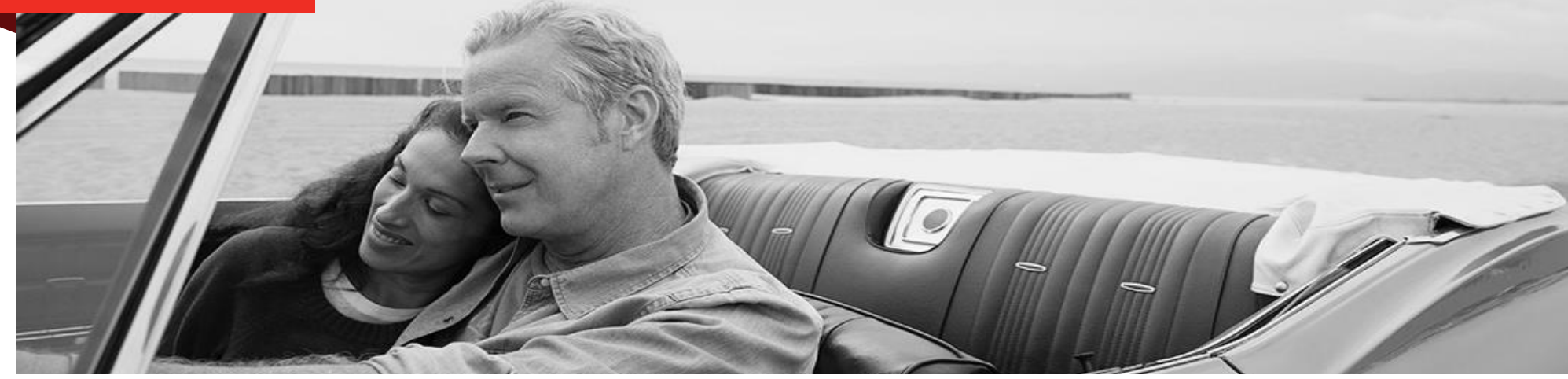

Benenson Strategy Group and GS Strategy Group conducted 1600 interviews - by phone, using registered voter lists - with likely 2020 voters in North Carolina from August $30^{\text {th }}$ to September $8^{\text {th }}$. $80 \%$ of interviews were conducted via cell phone; $20 \%$ via landline.

The survey included an oversample of $120050+$ voters for additional analysis, including 400 African-American 50+ voters.

Data was weighed to ensure it was representative of the likely voting universe both overall and 50+.

The margin of sampling error for the entire data set is $\pm 2.5 \%$ at the $95 \%$ confidence level.

- Among likely voters over the age of 50 , the margin of sampling error is $\pm 2.9 \%$ at the $95 \%$ confidence level.

Due to rounding, answer choices may not always add up to $100 \%$.

Please note that due to rounding, a sum may appear to be one point more or less than its parts.

Note: All reported data is among 50+ likely voters except when otherwise specified.

Partisan crosstabs in this report represent how people are registered on the voter rolls, not how they identify themselves.

For more information, contact Kate Bridges at kbridges@aarp.org

North Carolina Report - https://doi.org/10.26419/res.00401.007 